\title{
HYDRAULIC PERFORMANCES OF VARIOUS DRIPPERS USED IN IRRIGATION SYSTEMS IN NORTH SINAI
}

\author{
${ }^{*}$ M. T. Abd-Elsalam; * * A. A. Elsebsy; \\ ${ }^{* * *}$ Y. I. Abdullah; and ${ }^{* * * * M}$. A. Rashad
}

\begin{abstract}
The hydraulic performances of five commonly on-line emitters (Eml, Em2, Em3, Em4; Em5) were evaluated at the hydraulic laboratory of Agricultural Engineering Department, Agriculture Faculty, Suez Canal University, Ismailia, Egypt in October 2011. The test was under five operating pressure between 20 to $130 \mathrm{kPa}$. Em1, Em2, and Em3 were imported; the first type had pressure compensating flow, and the others with turbulent flow. While Em4, and Em5 types were locally manufactured with turbulent flow regime. Em5 is the most common in Sinai region because of its cheap price, although it had unacceptable coefficient of variation values. The measured or/ actual discharges for most emitter types were excess than the nominal discharge under $100 \mathrm{kPa}$ operating pressure, by these percentages: 6.93, 0.0, 5.5, 165, and 640\% for Em1, Em2, Em3, Em4, and Em5, respectively.
\end{abstract}

Keywords: Drip irrigation, Hydraulic performance, Manufacturer coefficient of variation, Emitter type.

\section{INTRODUCTION}

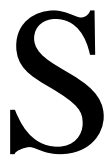
inai is an arid area: the temperatures cover wide daily and seasonal ranges, the rainfall is low and the evaporation rates high. Sinai is a faraway from the Nile with limited underground water resources. This area is important for Egypt's economic growth (Abou Rayan et al., 2001). In some parts of Sinai, the local inhabitants must use salty groundwater as potable water in the face of the water crisis (Elewa and Qaddah, 2011).

Drip irrigation generally improving the water-use efficiency (WUE), in addition dilution of soil solution's salt concentration. (Tagar et al., 2010).

\footnotetext{
* M.Sc. Student. Dept. of Soil \& Water (Agric. Eng.), Fac. of Environ. Agric. Sci.,

** Professor Emeritus of Soil \& Water, Soil \& Water Dept., Fac. of Environ. Agric. Sci., *** Lecturer of Agric. Eng., Soil \& Water. Dept., Fac. of Environ. Agric. Sci., **** Lecturer of Agric. Eng., Agric. Eng. Dept., Fac. of Agric.; all the four from Suez Canal University.
} 
The actual emitter discharge rate for typical field layouts varies considerably, and is very sensitive to pressure variation throughout the pipe distribution network, topographic variation (slope), partial or complete emitter clogging, design emitter characteristics, emitter manufacturer variation, emitter wear, water quality variation and temperature variation (Keller and Karmeli, 1974; El Awady et al., 2008; Tagar, et al., 2010).

Coefficient of Manufacturer's Variation in discharge describes the quality of the processes used to manufacture emission devices. This implies that it is possible to obtain variable flow rate from emitters by the same manufacturer (Awe and Kola, 2011). Manufacturing of an emission device must be precise because the emitter flow path is usually small, less than $2 \mathrm{~mm}$ in diameter (Ghaemi, 1998). Small differences between what appears to be identical emitters may result in significant discharge variations (Kirnak et al., 2004).

Unless care is taken in manufacturing emitter, plastic parts can be subject to considerable variation. There are a number of control variables for a molding machine, such as pressure and temperature, injection speed, mold temperature, cycle time, cooling rate, mold operation, and mold damage. Changing any of these factors causes a change in the conditions of the plastic being molded; these in turn affect the ultimate characteristics of the part produced, size, shape, weight, strength and surface finish. In addition a high $C v$ could occur due to a heterogeneous mixture of the materials used in the production of emitters (Kirnak et al., 2004; Hassan, 2007; Tagar et al., 2010).

The emitter discharge exponent $(x)$; is a measure of the sensitivity of the emitter flow rate to changes in pressure. This exponent is dimensionless and it is independent of the units used to measure flow rate and pressure (Smajstrla et al., 2011). The value of $x$ typically falls between 0.0 and 1.0 mainly depending on the make and design of the emitter, i.e. hydraulic characteristics.

Moshe Sne, (2006) reported that the water flows along a labyrinth in which the flow direction changes abruptly, that result in turbulent flow, high-energy losses and decreased flow-rate (emitter discharge exponent ' $x$ ' is about 0.5 ). Pressure-compensating emitters use excess inlet pressure 
to modify the shape, length, or diameter of the flow path to control the discharge rate by a diaphragm made of silicon or other elastic material. As the pressure increases, the diaphragm restricts the passage diameter, the friction head losses increases that keep the flow rate constant (' $X$ ' is normally less than 0.1 ).

\section{MATERIALS AND METHODS}

\subsection{Emitters:}

Figure (1) shows the five on-line emitter types with nominal discharge of $4 \ell / \mathrm{h}$ at $100 \mathrm{kPa}$. Five emitter types were used. An emitter samples each of 40 pieces were tested using the hydraulic calibration unit, see Fig. (2).

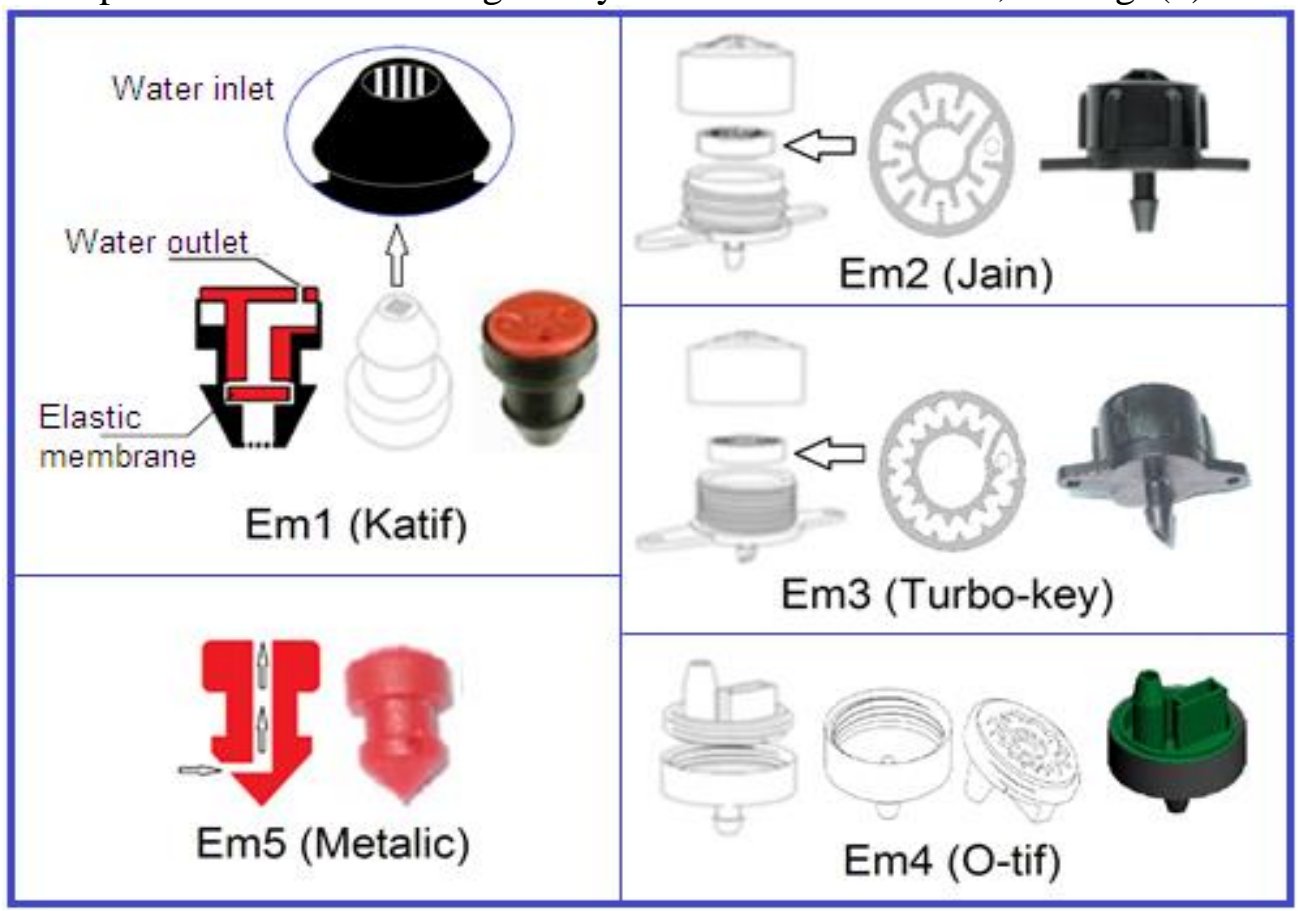

Figure (1): Photograph and schematic 3D model of the calibrated drippers.

The indicated symbols in this study and nominal discharges in the market for different emitter types are show in Tab. (1). 
Table (1): The symbols, nominal discharges, and flow-path dimension of the emitter types.

\section{Emitter}

\begin{tabular}{ccccc}
\hline Type & Symbol & Trademark & $\begin{array}{c}\text { Minimum flow- } \\
\text { path dimension } \\
(\mathbf{m m})\end{array}$ & $\begin{array}{c}\text { Nominal } \\
\text { discharge } \\
(\ell / h)\end{array}$ \\
\hline PC $^{*}$ & Em1 & $\begin{array}{c}\text { Katif } \\
\text { (Plastro) }\end{array}$ & 0.14 & 3.75 \\
\hline & Em2 & Jain & 0.97 & 4.00 \\
\cline { 2 - 5 } & Em3 & Turbo-key & 0.95 & 4.00 \\
\cline { 2 - 5 } $\mathbf{T F}^{* * *}$ & Em4 & O-tif & 1.04 & 4.00 \\
\cline { 2 - 5 } & Em5 & Metalic & 1.18 & 4.00 \\
\hline
\end{tabular}

${ }^{*} \mathrm{PC}=$ Pressure Compensating, ${ }^{* *} \mathrm{TF}=$ Turbulent Flow, ${ }^{* * *}$ Nominal discharge at100 kPa.

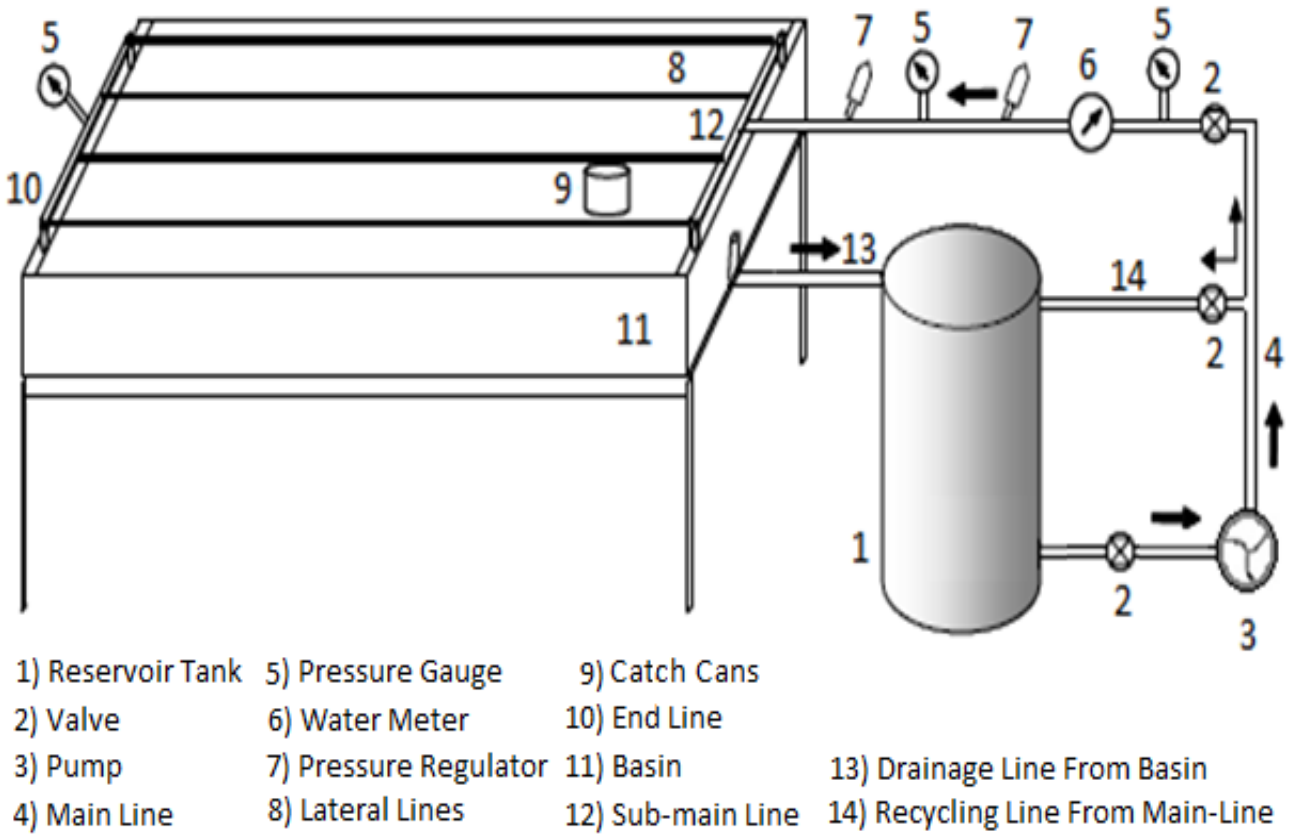

Figure (2): Diagram of the laboratory experimental layout for testing the hydraulic performance of the emitter types. 


\subsection{The hydraulic calibration unit components:}

Reservoir tank: made from plastic, cylindrical shape 127 liters volume, filled by municipal water, water outlet from the bottom and return to the top of the tank. Pump with power supply $220 \mathrm{~V}-50 / 60 \mathrm{~Hz}-1 \mathrm{HP}(0.74$ $\mathrm{kW})-5.2 \mathrm{~A}$, and $2800 \mathrm{rpm}$, the actual flow rates $1.2-6.0 \mathrm{~m}^{3} / \mathrm{h}$. Main line (cast-iron pipe) $24.5 \mathrm{~mm}$ diameter which carries pressure regulators, two bourdon pressure gauges (range 0.0 - $250 \mathrm{kPa}$ with $10 \mathrm{kPa}$ scale accuracy) to control the pressure, water meter and valves to get the desired discharge. 40 plastic collectors (2liters volume) for catching water from emitters were used. The basin for containing collectors was fabricated from galvanized steel sheet of $1.5 \mathrm{~mm}$ thickness, $175 \mathrm{~cm}$ long, $65 \mathrm{~cm}$ width and $18 \mathrm{~cm}$ height with total volume of 205 liters. The measured water pours into the basin and drainages to reservoir tank by a polyethylene (PE) drainage pipe which connected with an orifice on the bottom of the basin. Four lateral pipes (PE) of $14.5 \mathrm{~mm}$ (I.D) with $1.5 \mathrm{~m}$ length. The distance between the lines was $15 \mathrm{~cm}$, every line contains ten emitters at $15 \mathrm{~cm}$ spacing. The four lateral line's ends were connected together by one line (cast-iron pipe, $1.9 \mathrm{~cm}$ diameter) with a pressure gauge.

The emitter's characteristics were tested according to (Keller and Karmeli, 1974; ASABE, 2008), using a sample of fourteen new emitters from each type.

Emitter discharges were measured at five operating pressures of 20, 50, 80,100 and $130 \mathrm{kPa}$ and the flow rates were taken and measured by using two graduated cylinders: the first $500 \mathrm{ml}$ with $5 \mathrm{ml}$ scale accuracy and the other $100 \mathrm{ml}$ with $1 \mathrm{ml}$ scale accuracy, in a time of 3 minutes as indicated by a stop watch; to minimize error associated with starting and stopping of the runs and residual water in the containers.

Specific emitter flow functions, such as pressure flow relationship and manufacturer's coefficient of variation, were determined as follows:

\subsection{Criteria for assessing the hydraulic performance:}

Drip irrigation emitter flow rates have different responses to pressure variations. The response of a specific emitter depends on its design and 
construction. Emitter flow rate can be expressed by (Keller and Karmeli, 1974) as:

$$
q_{e}=k_{e} h_{e}^{x} \rightarrow(1)
$$

Where $q_{e}$ is emitter discharge rate $(\ell / \mathrm{h}), h_{e}$ is working pressure at the emitter $(\mathrm{kPa}), k_{e}$ is dimensionless constant of proportionality that characterizes each emitter, and $x$ is dimensionless emitter discharge exponent which characterizes the flow regime.

The variability of discharge can measure by taking a random sample of a given make, model and size of emitter as produced by manufacturer, and before any field operation (ASABE, 2008) as follows:

$$
C v=S D / q_{a} \rightarrow(2)
$$

In which $C v$ is manufacturer's coefficient of variation (dimensionless), $S D$ is standard deviation of discharge of emitters $(\ell / \mathrm{h})$, and $q_{a}$ is mean discharge of emitters in the sample $(\ell / h)$.

$$
S D=\left[\frac{\sum_{i=1}^{n}\left(q_{i}-q_{a}\right)^{2}}{n-1}\right]^{1 / 2} \rightarrow(3)
$$

Where $q_{i}$ is discharge of an emitter $(\ell / \mathrm{h})$, and $n$ is number of emitters in the sample.

Flow variation $q_{v a r}$ could express as:

$$
q_{\text {var }}=\frac{\left(q_{\max }-q_{\min }\right)}{q_{\max }} \times 100 \rightarrow(4)
$$

Where $q_{\max }$ and $q_{\min }$ : maximum and minimum emitter discharge rate $(\ell / \mathrm{h})$, respectively.

\section{RESULTS AND DISCUSSION}

\subsection{Pressure-flow relationship:}

The nominal and measured flow rate, difference percentage of measured from nominal discharge, emitter discharge equation constants $\left(k_{e}, x\right)$, flow regime, and the manufacturer's coefficient of variation and its 
classifications are presents in Tab. (2). Great differences between nominal and measured discharges were recorded with local emitters (Em4 and Em5) by $165 \%$ and $640 \%$, respectively.

Table (2): Flow rate $(\ell / h)$, the difference percentages between nominal and measured flow rates, emitter discharge equation constants, flow regime and manufacturing coefficient of variation $C v$ for the five emitter types at $100 \mathrm{kPa}$.

\begin{tabular}{|c|c|c|c|c|c|c|c|c|}
\hline \multirow{2}{*}{$\begin{array}{l}\text { Emitter } \\
\text { type }\end{array}$} & \multicolumn{2}{|c|}{ Flow rate $(\ell / h)$} & \multirow{2}{*}{$\begin{array}{c}\text { Difference } \\
\text { Percentage } \\
(\%)\end{array}$} & \multicolumn{2}{|c|}{$\begin{array}{c}\text { Emitter } \\
\text { constants }\end{array}$} & \multirow{2}{*}{ Flow regime } & \multicolumn{2}{|c|}{$\begin{array}{c}\text { Coefficient of variation } \\
\qquad C v "\end{array}$} \\
\hline & Nominal & Measured & & $" k_{e} "$ & $" x "$ & & Value & Classification* \\
\hline Em1 & 3.75 & 4.01 & 6.93 & 7.60 & -0.14 & $\begin{array}{c}\text { Pressure } \\
\text { Compensating }\end{array}$ & 0.06 & Average \\
\hline Em2 & 4.00 & 4.00 & 0.00 & 0.38 & 0.52 & Turbulent & 0.04 & Excellent \\
\hline Em3 & 4.00 & 4.22 & 5.50 & 0.54 & 0.45 & Turbulent & 0.13 & Marginal \\
\hline Em4 & 4.00 & 10.60 & 165.00 & 1.22 & 0.47 & Turbulent & 0.24 & Unacceptable \\
\hline Em5 & 4.00 & 29.60 & 640.00 & 2.06 & 0.57 & Turbulent & 0.28 & Unacceptable \\
\hline
\end{tabular}

*ASABE standards, (2008).

In turbulent flow (TF) emitters (Tab. 2) and (Fig. 3), the emitter discharge was proportionally increased by increasing the operating pressure. By increasing pressure from 20 to $130 \mathrm{kPa}$, discharge was generally increased from (1.79 to 4.60), (2.11 to 4.80$)$ and (5.05 to 11.90$) \mathrm{l} / \mathrm{h}$ for Em2, Em3 and Em4, respectively. Meanwhile in the case of Em5, the operating pressure ranged only between 20 to $100 \mathrm{kPa}$ (because of its high flow-rate), and the discharge had been increased from (11.49 to 29.60) $\ell / \mathrm{h}$. But in the case of PC emitter (Em1), the discharge was proportionally decreased from (5.15 to 4.00 ) by increasing pressure from 20 to $130 \mathrm{kPa}$.

The statistical coefficient of determination for the pressure flow relationship was recorded higher values $\left(R^{2} \geq 0.99\right)$ with turbulent flow emitters, than PC emitter, see (Tab. 2) and (Fig. 3). High values of $R^{2}$ indicated that; Eq. (1) is an appropriate model to describe the relationship between the discharge and the pressure. This result was agreed with (Bralts and Wu, 1979; Ozekici and Bozkurt, 1999; Kirnak et al., 2004), they reported that: theoretically the compensating drip emitter 
discharges should not show any variation under different pressures. But, in the actual discharge measurements there were different discharges under variable pressures.
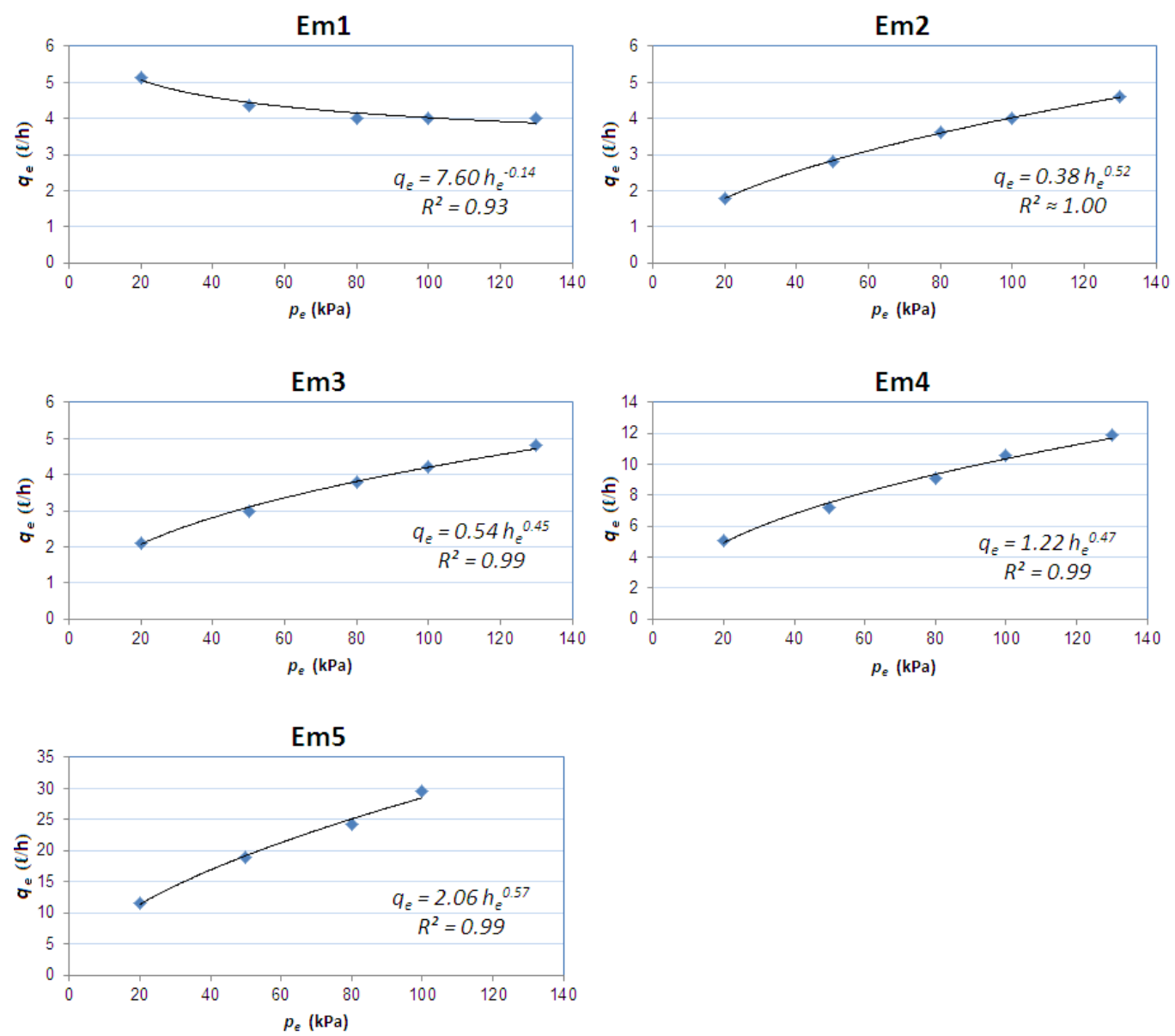

Figure (3): Relationship between operating pressures versus discharge for calibrated emitters (Em1, Em2, Em3, Em4; Em5).

A lower value of " $x$ " for PC emitters indicates lower sensitivity of flow rate to changes in pressure; a higher value of the turbulent flow emitters indicates higher sensitivity.

Table (2) and (Fig. 3) shows the calibration of tested emitter types, the constants $x$ and $k_{e}$ were determined for all emitter types using Eq. (1). The emitter exponent $(x)$ for PC emitter was a negative number close to zero (0.14 ), which mean that emitter flow rate was slightly decreased with 
pressure increase. Where, the $x$ values were around 0.5 and ranged from 0.45 to 0.57 for turbulent flow emitters, indicating relatively increase in the emitter flow rate by increasing the operating pressure.

The emitter discharge coefficient $\left(k_{e}\right)$ values ranged from 7.60 to 0.38 . The results were shown a compatible $x$ values with the classification of the manufacturers of these emitters.

\subsection{Coefficient of variation $(\mathrm{Cv})$ :}

The $C v$ classifications of the five emitter types are present in Tab. (2) and Fig. (4), the results showed that; $C v$ classification of emitter discharge under $100 \mathrm{kPa}$ operating pressure was average with Em1, which has pressure compensating flow (PC). While it were varied with turbulent emitters types from excellent for Em2 to marginal with Em3, and unacceptable with Em4 and Em5.

Manufacturer's coefficient of variation $(C v)$ values of the PC emitters were higher than those of $\mathrm{TF}$ emitters, because it was difficult to manufacture the movable parts in the PC emitters (Ozekici and Sneed, 1995; Ozekici and Bozkurt, 1999; Hassan, 2007 and Tagar et al., 2010). Previous results applies to Em 2 type only, while the other three emitters (Em3, Em4; Em5) showed higher $C v$ values than imported PC emitter (Em1); due to low manufacturing level for it in the industry.

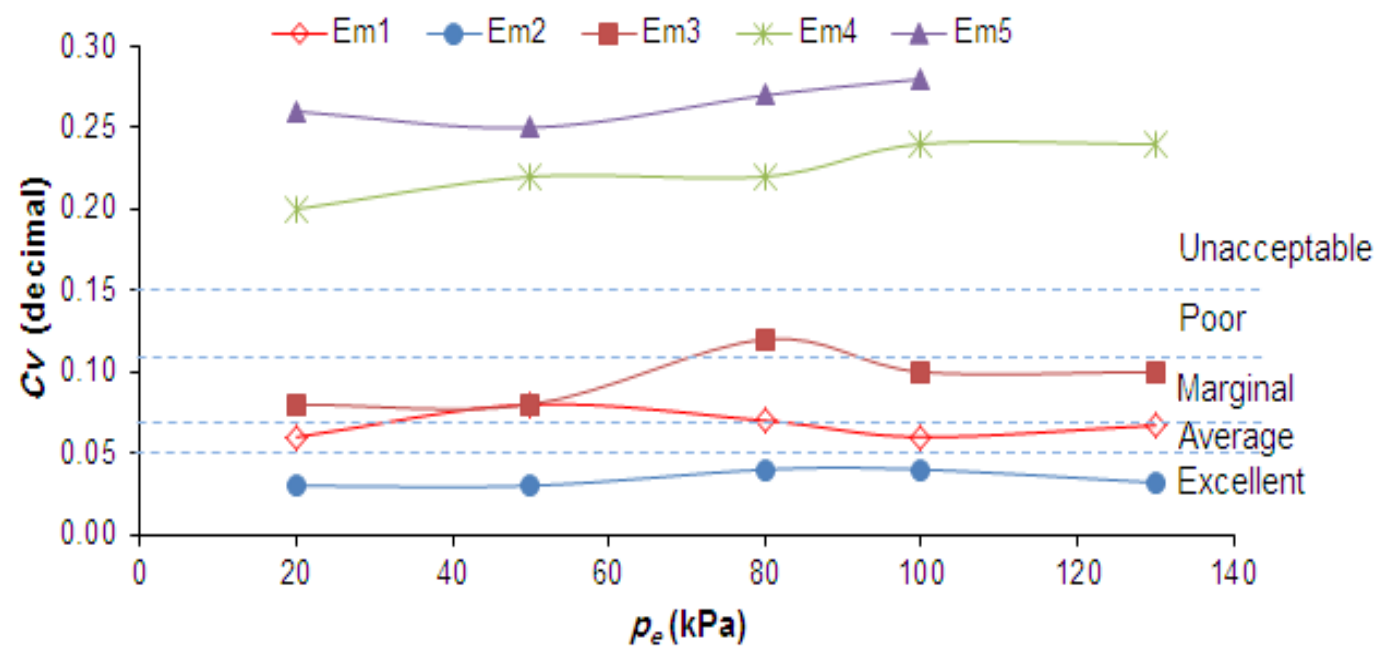

Figure (4): Relationship between operating pressures versus manufacturer's coefficient of variation $(C v)$ for calibrated emitters. 
The $C v$ classification (ASABE, 2008) in Fig. (4), where are as follows: excellent category $(C v<0.05)$, average $(0.07>C v>0.05)$, marginal $(0.07>C v>0.05)$, poor $(0.07>C v>0.05)$, and unacceptable $(C v>0.15)$.

Figure (4) indicate that all $C v$ values of Em4 and Em5 befallen in the unacceptable range $(C v>0.15)$. While all the $C v$ values for Em3 were classified as marginal $(0.11>C v>0.07)$, except one value at $80 \mathrm{kPa}$ was in the poor range $(0.15>C v>0.11)$. All $C v$ values for Em1 were stated in the average range $(0.07>C v>0.05)$, except one value at $50 \mathrm{kPa}$ pressure where the $C v$ value was upraised to the marginal category. All $C v$ values of Em2 were in the excellent range $(C v<0.05)$.

Overall there was no systematic pattern in all emitter's $C v$ values, indicating no obvious regular increase or decrease with increases in pressure (Fig. 4). The $C v$ values were relatively insensitive to operating pressure in accordance with (Hassan, 2007).

\subsection{Emitter flow variation:}

Calculation of $q_{v a r}$ using Eq. (4) showed that; the mean value of $q_{v a r}$ at operating pressures ranging from 20 to $130 \mathrm{kPa}$ for (Em1, Em2, Em3; Em4) were $(26.02,15.30,35.79 ; 60.93 \%)$, respectively. Meanwhile the mean value of $q_{v a r}$ for Em5 was $69.11 \%$ under 20 to $100 \mathrm{kPa}$ operating pressures.

Hence the effect of emitter type on the flow variation could be stated in the following descending order: Em5 $>$ Em4 $>$ Em3 $>$ Em1 $>$ Em2.

The maximum and minimum values of $q_{v a r}$ for the Em1, Em2, Em3, Em4 and Em5 were $(30.80 ; 22.29 \%),(19.04 ; 11.28 \%),(38.08 ; 33.58 \%)$, $(64.28 ; 51.35 \%)$ and $(72.81 ; 66.36 \%)$ respectively, created by operating pressures of $(50 ; 130),(80 ; 50),(130 ; 50)(80 ; 20)$ and $(100 ; 50) \mathrm{kPa}$, these results are present in Fig. (5). Desirable $q_{v a r}$ values were below 10\%, acceptable between 10 to $20 \%$, and unacceptable above $20 \%$, according to (Camp et al., 1997; Clark et al., 2007). 


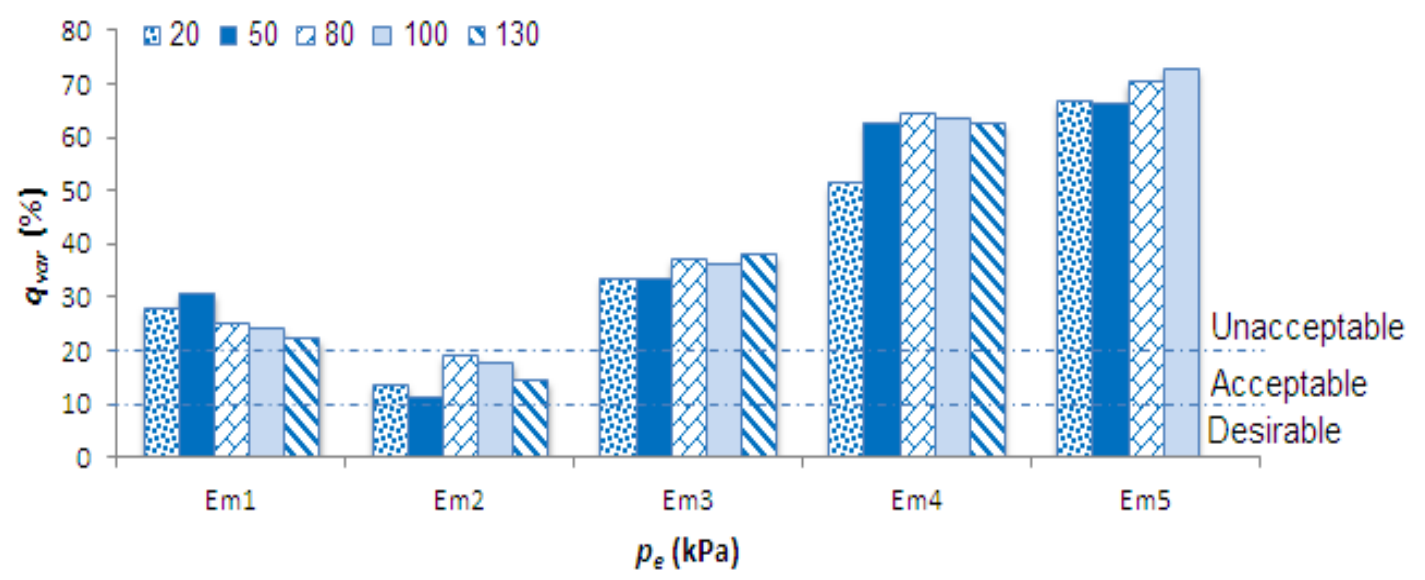

Figure (5): Relationship between operating pressures $\left(p_{e}, \mathrm{kPa}\right)$ versus emitter flow variation $(\%)$ for calibrated emitters.

Finally it can be seen that; the maximum values of $q_{v a r}$ were under pressures of $80 \mathrm{kPa}$ or higher for all TF emitter types, but Em1 (PC emitter) had the maximum $q_{v a r}$ value with a pressure of $50 \mathrm{kPa}$. The lowest $q_{\text {var }}$ values were by pressures 50 and $20 \mathrm{kPa}$ for all tested emitters, except for the Em1 where the lowest $q_{v a r}$ value was under $130 \mathrm{kPa}$ operating pressure. All tested emitters hadn't desirable $q_{v a r}$ values under all operating pressures, the whole $q_{v a r}$ percentages of Em2 only had acceptable flow variation percentages $\left(q_{v a r}<20 \%\right)$ under all operating pressures.

\section{RECOMMENDATIONS}

We can recommend from the previous study that:

1. The design of drip irrigation network should base on reliable laboratory test data, not on published data by manufacturers. Serious manufacturers only who published the actual specifications of the product.

2. Locally manufacturing of high quality emitter types with suitable selling prices.

3. Spread awareness between farmers via the agricultural extension views over the water shortages in the near future and the importance of water resources saving and improving water distribution efficiency. 
4. Emitter type Em5 is widely common handled in the region; it had very high $C v$ values moreover the massive water consumption. However its smallest price it's not recommended to use. But the expensive price represents the substantial obstruction for adopting high quality drippers.

\section{REFERENCES}

Abou Rayan, M.; B. Djebedjian and I. Khaled, (2001). Water supply and demand and a desalination option for Sinai, Egypt. Desalination, (136): 73-81.

ASABE STANDARDS, (2008). Design and installation of microirrigation systems. ASAE EP405.1 APR1988: 1-5.

Awe, G. O. and O. Kola, (2011). Performance evaluation of Bamboo (Bambusa Vulgaris, Schrad)-pipe and medi-Emitter in a gravityflow drip irrigation. International J. of Agric. and Forestry, 1(1): 913.

Bralts, V.F. and I.P. Wu, (1979). Emitter flow variation and uniformity for drip irrigation. ASAE, St. Joseph, Michigan, USA: 79-2099.

Camp, C.R.; E.J. Sadler and W.J. Busscher (1997). A comparison of uniformity measure for drip irrigation systems. Transaction of the ASAE, 40: 1013-1020.

Clark, G. A.; D. Haman; J. F. Prochaska and M. Yitayew, (2007). Micro Irrigation for Crop Production (General system design principles). Elsevier: 161-215.

El-Awady, M.N.; A.M. El-Berry; M. A. El-Genaidy and A. M. Zayton, (2008). Hydraulic properties effect of filter media on emitter clogging proplems; Misr J. Agric. Eng., 25 (3): 824-836.

Elewa, H. and A. Qaddah, (2011). Groundwater potentiality mapping in the Sinai peninsula, Egypt, using remote sensing and GISwatershed-based modeling. Hydrogeology J., (19): 613-628. 
Ghaemi, A., (1998). Impact of different patterns of emitter clogging on hydraulic characteristics of micro-irrigation laterals laid on flat and sloped terrains, Ph.D. Th., Chemical and Bio-Resource Engineering., Fac. of Graduate Studies., British Columbia U.: 1039.

Hassan, N. S. H., (2007). Evaluation of trickle irrigation designs based on uniformity concept. M.SC. Dept. of Agric. Eng. Fac. of Agric., Ain Shams U., Egypt: 18-33.

Keller, J. and D. Karmeli, (1974). Trickle irrigation design parameters. Transaction of the ASAE, Vol., 17(4): 678-684.

Kirnak, H.; E. Dogan; S. Demir and S. Yalcin, (2004). Determination of hydraulic performance of trickle irrigation emitters used in irrigation systems in the Harran Plain. Turk. J. Agric. Forest., (28): 223-230.

Moshe Sne, (2006). Guidelines for Planning and Design of Micro Irrigation In Arid And Semi-Arid Regions. International commission on irrigation and drainage (ICDI): 1-14.

Ozekici, B. and R. Sneed, (1995). Manufacturing variation for various trickle irrigation on-line emitters. Appl. Eng. Agric. St. Joseph. MI: ASAE, 1985-Mar. V.II (2): 235-240.

Ozekici, B. and S. Bozkurt, (1999). Determination of hydraulic performances of in-line emitters. Tr. J. of Agric. and Forestry, 23: 19-24.

Smajstrla, A.G.; B.J. Boman; D.Z. Haman; D.J. Pitts and F.S. Zazueta, (2011). Field evaluation of micro-irrigation water application uniformity. Agricultural and biological engineering department. Florida cooperative extension service. Institute of food and agricultural sciences, Florida U.

Tagar, A. A.; M. S. Mirjat; A. Soomro and A. Sarki, (2010). Hydraulic performance of different emitters under varying lateral lengths., Pak. J. Agri., Agric. Eng., Vet. Sci., 26 (2): 48-59. 


\section{الملخص العربى}

\section{الأداء الهيارولى لأنواع نقاطات مستخدمة بأنظمة الرى بشمال سيناء الرئاء}

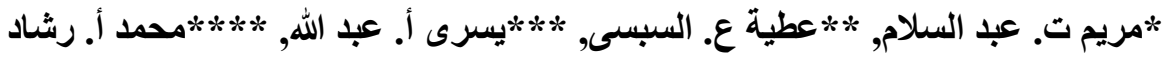

تم تقييم الخو اص الهيدرولية لخمس أنواع نقاطات متاحة فى السوق المحلى: أحدهم نقاط معوض للضغط (Em1) والأخرون Em2 و Em3 و هـى نقاطات ذات سريان مضطرب مستوردة, بينما Em4 و Em4 Eقاطات ذات سريان مضطرب محلية الصنع. وذلك فى معمل الهيدروليكا بقسم

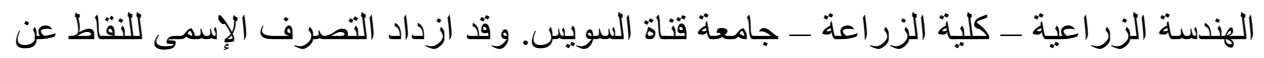

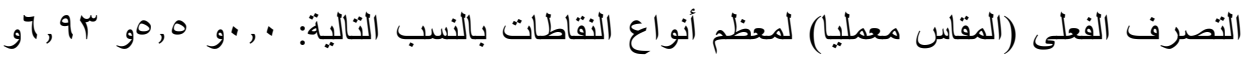

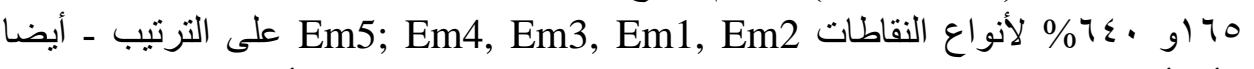

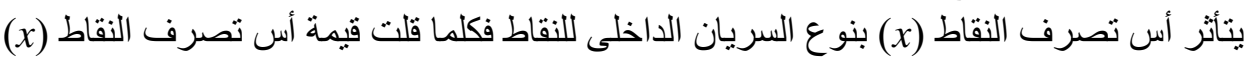
يقل تأثر التصرف بإختلاف ضغوط التشغيل - وحقتت جميع أنواع النقاطات المضطربة السريان

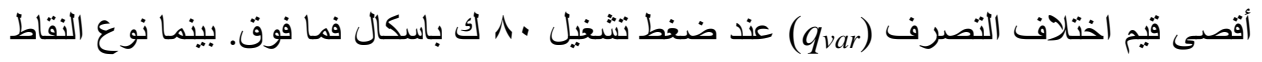

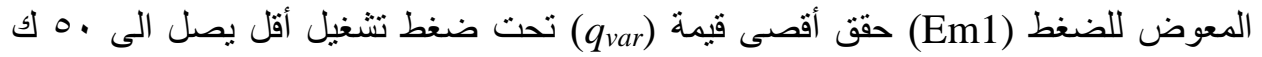

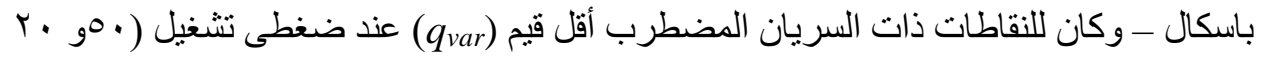

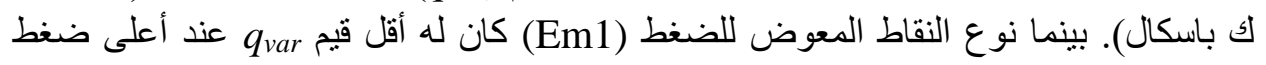

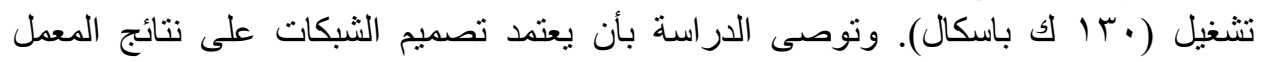

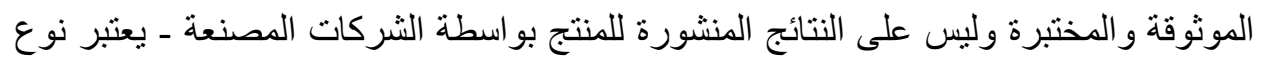

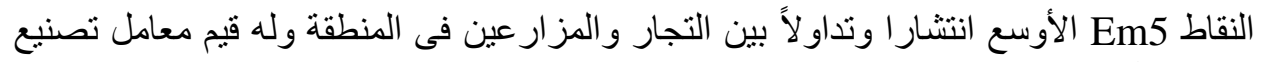

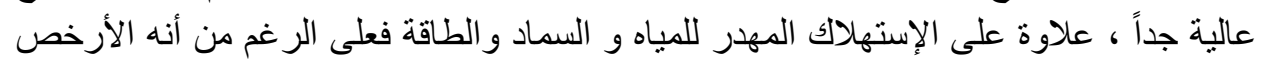

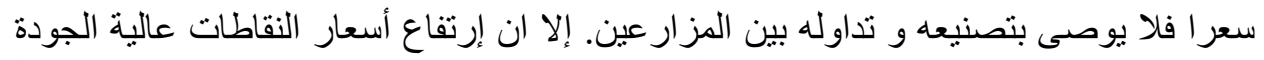

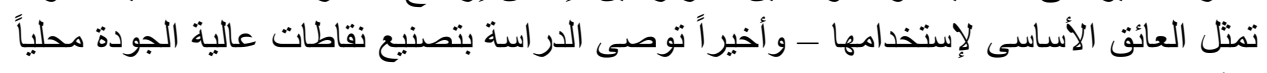
وبأسعار مناسبة.

*طالبة ماجستير - قسم الأراضى والمياه (هندسة زراعية)- كلية العلوم الزراعية البيئية بالعريش- جامعة قناة السويس.

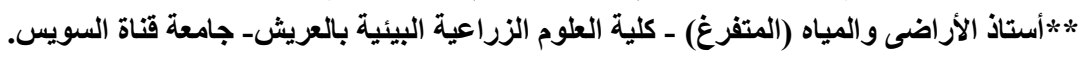

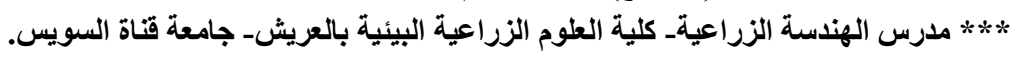
**** مدرس الهندسة الزراعيةـ كلية الزراعة - جامعة قناة السويس. 